Зінчук, Руслана. «Волинсько-поліська говірка в романі Володимира Лиса «Стара холера»: морфологічний рівень». Лінгвостилістичні студії, вип. 12, 2020, с. 62-72.

Zinchuk, Ruslana. "Volyn-Polissian Dialect in Volodymyr Lys's Novel "Old Cholera": Morphological Level". Linguostylistic Studies, iss. 12, 2020, pp. 62-72.

УДК 811.161.2'28+821.161.2'06.08Лис.В

https://doi.org/10.29038/2413-0923-2020-12-62-72

\title{
ВОЛИНСЬКО-ПОЛІСЬКА ГОВІРКА В РОМАНІ ВОЛОДИМИРА ЛИСА «СТАРА ХОЛЕРА»: МОРФОЛОГІЧНИЙ РІВЕНЬ
}

\author{
Руслана Зінчук \\ Східноєвропейський національний університет імені Лесі Українки, \\ Луцьк, Україна
}

Проаналізовано морфологічні особливості волинсько-поліської говірки в тексті роману Володимира Лиса «Стара холера». Прокоментовано специфіку формотворення іменників, діалектні вияви в словозміні прикметників, відмінності у структурі та відмінюванні займенників, а також в оформленні числівників, говіркові особливості дієвідмінювання та відмінності в морфемному складі прислівників. 3'ясовано специфіку використання автором волинсько-поліських живомовних елементів.

Ключові слова: волинсько-поліська говірка, словозміна, закінчення, архаїзм, граматична аналогія, фонетична інновація.

\section{VOLYN-POLISSIAN DIALECT IN VOLODYMYR LYS'S NOVEL “OLD CHOLERA”: MORPHOLOGICAL LEVEL Ruslana Zinchuk \\ Lesya Ukrainka Eastern European National University, Lutsk, Ukraine}

Incorporating dialect phenomena into modern literary text and the study of the individual author's technique of using them in literary work is one of the most topical issues of modern linguistics. It is an important source of information about the trends of dialect and literary language interaction.

In this context, the writers' interest in North-Ukrainian dialects deserves special attention, in particular, the actualization of the Volyn-Polissian lingual elements in fiction. Volodymyr Lys shows unique mastery in reproducing the vivid dialect elements of Volyn Polissia in his works.

The source of factual material for the case study is the novel Old Cholera by Volodymyr Lys. Although a considerable amount of research has been devoted to the writer's artistic language, few attempts have been made to investigate this novel, and it contains rich material for linguistic and dialectological studies.

The purpose of the study is to trace the morphological features of the Volyn-Polissian dialect in Volodymyr Lys's novel Old Cholera.

The study of the analyzed material has revealed that the writer conveyed, in the most detailed and consistent way, the dialectal differences in phonetic design, morpheme structure, and inflection of pronouns. Expressive dialectal phenomena illustrate the specifics of the formation of nouns and differences in the morpheme composition of adverbs. Several examples present local features of the phonetic framing and inflection of numerals.

(C) Зінчук Р., Східноєвропейський національний університет імені Лесі Українки, 2020.

Це стаття відкритого доступу на умовах CC BY-NC 4.0 
Differences in the system of adjective formation are evidenced by single dialectal phenomena. The examples with local verbs declension features are limited in number. Given the origin, morphological innovations dominate, the reasons for which are typical for the described area phonetic patterns, and similar processes.

The individual author's feature of using the elements of dialect speech not only in the dialogues of characters but in the author narrative is considered as a successful artistic technique. It impresses with the effect of natural speech and is perceived as a subjective narrative-confession.

Key words: Volyn-Polissian dialect, inflection, ending, archaism, grammatical analogy, phonetic innovation.

Вступ. Художній текст як «складний естетичний феномен, кожен елемент якого вмотивований, оскільки співвіднесений із загальним творчим задумом автора» (Черевченко 227), віддавна привертає увагу науковців, стаючи цінним джерелом різноаспектних лінгвістичних студій, зокрема й тих, які розкривають особливості діалектно-літературної взаємодії. Українську художню прозу вирізняє традиція використання територіально здиференційованих елементів, які за посередництвом художньо-естетичної функції мови впливають «на динаміку стильових норм, а також на загальнолітературну норму» (Єрмоленко 198). Діалектизми - своєрідні «маркери локальної прив'язаності художньої оповіді» - сприяють відтворенню природного колориту спілкування людей (Єрмоленко 200), відображають відповідну ментальність і світобачення, забезпечують мовну й етнографічну ідентифікацію персонажів (Яворський 16).

У цьому контексті заслуговує на увагу зацікавлення письменників північноукраїнськими говірками, зокрема актуалізація в белетристиці волинсько-поліських лінгвальних елементів. Особливу майстерність у відтворенні живомовної стихії Волинського Полісся виявляє Володимир Лис, художня мова якого вже стала об'єктом активного наукового опрацювання. Детальний опис таких досліджень подає в дисертаційній роботі А. Яворський (5), водночас пропонує власний грунтовий аналіз різнорівневих діалектизмів у романах «Століття Якова», «Іван і Чорна Пантера», «Соло для Соломії», у книзі «Із сонцем за плечима. Поліська мудрість Пелагеї», якими В. Лис увів у сучасну художню літературу говірку рідного села Згорани на Волині (Яворський 6-8).

2018 року з'явився роман В. Лиса «Стара холера». Цей текст дотепер не був об'єктом спеціального вивчення, хоча й містить цікавий для лінгвостилістичних та діалектологічних студій матеріал.

Мета статті - простежити морфологічні особливості волинськополіської говірки в тексті роману В.Лиса «Стара холера». Реалізація поставленої мети передбачала виконання таких завдань дослідження: зафіксувати і систематизувати використані автором говіркові одиниці морфологічного рівня; прокоментувати виявлені в тексті діалектні явища 
3 погляду походження; простежити індивідуально-авторську специфіку використання елементів волинсько-поліської говірки.

Матеріал і методи дослідження. Джерельна база роботи - роман В.Лиса «Стара холера». Дослідження фактичного матеріалу проведене методом лінгвістичного опису, сукупність прийомів якого уможливила виділення одиниць аналізу, їх диференціацію та класифікацію. Для вивчення специфіки діалектних морфологічних явищ використано зіставний метод.

Результати дослідження та дискусія. Романом «Стара холера» В. Лис уводить у художню літературу говірку витвореного власною уявою поліського села Туптали (порівняймо 3 назвами населених пунктів Волинської області, як-от: Тупали Турійського району, Гупали Любомльського району). У тексті автор так означує цю локацію: 8 далекому селі на Поліссі зі смішною назвою Туптали (Лис 242), ... народилася в селі Туптали на Волині (Лис 252). «Письменник майстерно передає говірку своїх сільських героїв, включно 3 характерними діалектними слівцями», - стверджує Я. Поліщук у рецензії на роман «Стара холера». Це, на думку рецензента, «безумовний здобуток Володимира Лиса, що позначається не тільки власне в діалогах, а й у передаваних через мову автора внутрішніх монологах та роздумах» (Поліщук).

У романі актуалізовано різнорівневі говіркові елементи, зокрема й виразні явища волинсько-поліської словозміни, що стали предметом пропонованого дослідження.

Так, відмінності супроти літературної мови простежено в системі формотворення субстантивів. Поширену в говірках Волинського Полісся нейтралізацію протиставлення за твердістю / м'якістю в сингулярній парадигмі іменників засвідчують пропоновані автором відмінкові варіанти власних назв, зокрема форми давального та орудного відмінків однини онімів: нашому Адасьові (Лис 13), одказ Грицьові Лучикові (Лис 28), батька Клепцьом прозивали (Лис 15), з моїм Прокіпцьом (Лис 101).

Оформлення давального відмінка однини іменників-назв істот, яке в обох мовних системах (і літературній, і діалектній) на сучасному етапі їх розвитку позначене передусім інтегруючою силою відповідних виявів іменників давньої вокалічної *-й-основи, у народнорозмовній і художній традиції нерідко засвідчує наслідки впливу відмінкових форм субстантивів колишніх *-о̌-, *-јо̆-основ; порівняймо фіксації в тексті роману: Адамові ж треба було літати (Лис 84), розкаже Степанові (Лис 96), донесеш Федотові? (Лис 114), Адамові хотілося сказати (Лис 115), не сказав Федотові (Лис 115), не сказала Максимові (Лис 216), налив собі й Адаму (Лис 130), Федоту призналася (Лис 131), Адаму що тре', яко чоловікові? (Лис 14).

Специфіку формотворення знахідного відмінка однини іменниківназв неістот передано через практично послідовне використання В. Лисом у цій позиції відповідних виявів родового відмінка однини аналізованих 
субстантивів, як-от: на цепа посадила (Лис 117), складемо протокола (Лис 125), вона йому гріха приписувала (Лис 129), на зуба покласти (Лис 130), відкрутив крана (Лис 164), поклав у кошика (Лис 179), пішов дивитися ... телевізора (Лис 180), вручити букета (Лис 193), відчинила холодильника (Лис 217), вів щоденника (Лис 230), дав ключа од кімнати (Лис 230), приклав рупора до вуст (Лис 264). У тексті автора-оповідача спорадично фіксуємо варіантні флексії засвідченої відмінкової позиції; порівняймо форми іменника конверт: вручив їй конверта (Лис 136), Ліза відкрила конверт (Лис 136).

Кількома словозмінними афіксами В.Лис ілюструє особливості формотворення місцевого відмінка однини субстантивів-назв неістот. Це, зокрема, закінчення -i, яке «становить собою з походження фонетично змінену давню флексію *е̌ іменників колишніх *-о̆-основ» (Iсторія української мови 97-98): йти вечорами по селі (Лис 87); флексія -у, що первісно була характерна для відповідних словозмінних виявів субстантивів давніх *-й-основ (Історія української мови 98): б'ють по тілу й по животу (Лис 20), по селу їх розносила (Лис 25); закінчення -ові як фонетичний варіант флексії давального відмінка однини іменників колишніх *-й-основ, що «прийняла на себе згодом і функції місцевого відмінка однини» (Історія української мови 98): на лужкові назбирала (Лис 177).

Збережені в народнорозмовній традиції Волинського Полісся форми субстантивів середнього роду на -'e відповідно до давнього *-ьје іменників колишніх вокалічних *-јǒ-основ засвідчено досить продуктивною в мовленні персонажів роману формою життє: ціле своє життє любив неї (Лис 27), всеньке життє мене так любив (Лис 27), життє пройшло повз мою хату (Лис 47), що ж то за життє таке настало (Лис 267).

Одну з особливостей консонантної системи волинсько-поліських говірок В. Лис ілюструє формою з депалаталізованим сонорним вібрантом перед закінченням давального відмінка множини іменника, порівняймо: курам їсти дати (Лис 117).

Кількома прикладами представлено діалектні відмінності в реалізації категорії роду субстантивів. Родове переосмислення іменника, пов'язане з його флексійним переоформленням, засвідчує вжита одним із персонажів роману форма називного відмінка однини субстантива телефон, як-от: у неї ж та тіліфона $\epsilon$ (Лис 261). Рідну живомовну традицію В. Лис передає також поширеною в говірках Волинського Полісся формою дома та її відмінковими варіантами, порівняймо: дома, в якій тепер жив, називалася празником (Лис 176), з другої доми (Лис 8), коло доми свеї (Лис 18), до доми меї (Лис 27), вибігла з Адамової доми (Лис 85), прогнали з доми (Лис 85), до свеї доми (Лис 99), біля вікон свеї доми (Лис 112), прийшла до його доми (Лис 113). Закріплену літературною нормою форму аналізованого іменника фіксуємо в тексті роману спорадично: ніхто неї з дому не проганяв (Лис 85). 
Діалектну специфіку парадигми субстантива пані, що в літературній мові належить до невідмінюваних і має граматичне значення жіночого роду, визначають уживані автором форми знахідного та орудного відмінків однини: скаржитися ... на задрипану паню (Лис 82), вона якось поладиться і з тою панею (Лис 71).

3-поміж явищ ад'єктивного формотворення вирізняємо насамперед інновації аналогійного характеру. Тенденція до уніфікації за моделлю твердої групи, очевидно, вплинула на продуктивність суфікса -ов- після м'якого консонанта у використаних В. Лисом відмінкових формах присвійних прикметників жіночого роду: Адасьова, - сказала б вона (Лис 66), Кульової Маруськи (Лис 7), у родичів баби Параски Клецьової (Лис 9), у Ганки Трикальової (Лис 13), ген уже коло Мотрунки Дрикальової (Лис 99), Єву Клепцьову (Лис 15), а хотя б із Євкою Клепцьовою (Лис 14).

Нечленну форму прикметника фіксуємо в етикетному виразі, як-от: здоров був, босяцький пане (Лис 63). Щоправда, у подібних мовних формулах, на думку Н. Крижанівської, лексеми здоров (оставайся здоров, друже мій), ласкав (порадь, будь ласкав) «втрачають номінативну функцію, поривають із категорією прикметника і переходять у категорію вигуку» (18).

Найбільше відмінностей супроти літературної мови простежено у фонетичному оформленні, морфемній будові та словозміні виявлених у тексті роману займенників. Так, специфіку формотворення особових займенників нерідко визначає позиційна реалізація ненаголошеного [e], зокрема підвищення і звуження артикуляції [е] > [и]; порівняймо оформлення першого ненаголошеного складу у формах давального та знахідного відмінків займенника I особи однини: мині й ніц ни тре було (Лис 63), ніщо вже мине од тої жінки не порятує (Лис 97), а також варіанти родового та знахідного відмінків займенника II особи однини: до тибе прийшли (Лис 16), од тибе, Євочко (Лис 26), хіба я тибе колись обманював? (Лис 101), коло тибе постою (Лис 118), у тибе підлога тепла (Лис 118), хтось до тибе припреться (Лис 261), хто б тибе спас? (Лис 265).

В. Лис передає народнорозмовну традицію, використовуючи також виразний західнополіський локалізм - форму ви-те займенника II особи множини: ага, то ви-те? (Лис 12), де то ви-те, тату (Лис 18), ви-те, дєдьку, брешете (Лис 24), ви-те посварилися, то й розбирайтеся (Лис 41), даремно ви-те так-о, ви-те б з нею мирно (Лис 83), а щоб ви-те вигоріли (Лис 83), ви-те сієте чортополох, бабо (Лис 84), ви-те, той-во, не сійте гарячку (Лис 259). Компонент -те у структурі аналізованого деривата, на думку Ю.Громика, «пов'язаний зі старою формою II особи множини теперішнього часу допоміжного дієслова быти, що виступала у відповідній формі перфекта, а в більшості південно-західних українських говорів збереглася як особова енклітика -c'me (-cme) при дієсловах минулого часу II особи множини» (288). Одиничним виявом у тексті роману представлений варіант висте займенника II особи множини: може, хоч висте порозумієтеся (Лис 62). 
За окремими живомовними свідченнями можна вирізнити формотворення предметно-особових прономінативів. Так, займенник чоловічого роду в родовому відмінку однини фіксований у формах од нього й $y$ него, які вказують на досі не завершений у говірках процес «закономірної зміни голосного [е] в [о] після [й] перед твердим приголосним» (Історія української мови 152): їдна тінь од нього (Лис 27), од нього тепло йшло (Лис 133), од нього ... могло простудитися (Лис 178), $y$ него і ружо $\epsilon$ (Лис 259).

Формотворення предметно-особового займенника жіночого роду в родовому та знахідному відмінках однини позначене активізацією приставного [н] незалежно від наявності прийменника: вірно неї ждав (Лис 7), куди неї вивезли (Лис 20), змусив неї підписати бомагу (Лис 21), любив неї (Лис 27), ніхто неї не просив (Лис 30), він учив неї танцювати (Лис 32), ні неї, ні Павлини (Лис 38), огортав неї (Лис 41), таки схожа на ту неї давню (Лис 46), прийшов, щоб неї побачити (Лис 69), він взяв неї за руку (Лис 75), Адамові стало неї жалко (Лис 85), неї позбавили права сваритися (Лис 86), як він смів неї покинути? (Лис 128), торкнувся неї своїм плечем (Лис 181), став неї шукати (Лис 183), тиша огортала неї (Лис 213), тривога облягла неї (Лис 258), неї вже й нема на світі (Лис 258), ніколи неї не обманювали (Лис 258), угледів неї Адам (Лис 266) та ін.

Аналізований займенник уживаний і в присвійному значенні. Щоправда, В.Лис часто використовує типову для волинсько-поліських говірок форму, утворену шляхом поширення структури неї суфіксом -H-, як-от: загубився неїн слід (Лис 9), неӥн син Федот (Лис 70), неїн Федотик (Лис 71), нібито неїн чоловік (Лис 118), зайшов неїн кіт (Лис 129), неїного батька (Лис 15), до неїного дзьоба гострого трапляє (Лис 97), неїного кота (Лис 181), і з сином неїним (Лис 25), правда неїна (Лис 28), неїна невістка Лізка (Лис 46), матір неїна (Лис 48), з неїної шиї (Лис 27), од неїної любові (Лис 28), неӥне життя (Лис 29), неїне щастя (Лис 35), неӥне бурчання (Лис 177), очі неїні побільшали (Лис 69), після неїних гріхів любив Катрусю (Лис 129), жили на кінчиках пучок неїних пальців (Лис 176).

у парадигмі присвійних займенників мій, твій, свій простежено специфічні стягнені форми непрямих відмінків, передусім родового: до доми меї (Лис 27), тепер меї душі нема (Лис 113), то ж у меї Каті (Лис 130), до спини твеї притулюся (Лис 183), коло доми свеї (Лис 18), до свеї хати (Лис 86), пішов до свеї оселі (Лис 87), до свеї доми (Лис 99), до свеї лежачої жінки (Лис 263), сина свего я не забуду (Лис 77), не слухаючи свего хазяїна (Лис 99). Випадіння звукосполуки [ой] фіксуємо також при формотворенні орудного відмінка однини прономінатива своя: з Любою свею (Лис 77), свею заздрістю, ревнощами й закувала (Лис 77), зі свею Катрусею (Лис 83), за свею кошаницею хочеш? (Лис 128). С. Бевзенко розглядає можливість упливу на засвідчені вияви присвійних займенників відповідних відмінкових форм вказівних прономінативів цей, це, ця, що постали 3 давніх ${ }^{*} \mathrm{cb},{ }^{*} \mathrm{ce},{ }^{*} \mathrm{cu}$ (171-172). Народнорозмовна традиція волинсько- 
поліських говірок зберігає такі форми, на що вказують, зокрема, уживані В. Лисом відмінкові варіанти вказівного займенника ця, як-от: до цеї халупи (Лис 13), до цеї бабці (Лис 65), що цеї ночі пережив (Лис 135), ти ближче до цеї жінки (Лис 181), засоромився цеї думки (Лис 183), цею молитвою (Лис 268).

Формотворення неособових родових займенників у досліджуваному матеріалі вирізняють також членні нестягнені форми вказівних прономінативів. Активно представлено відповідні вияви називного та знахідного відмінків однини жіночого роду: тая Євка-Ружа (Лис 97), ияя мара (Лис 118), тико ни тую Єву (Лис 14), через тую стіну (Лис 20), тую любов ... він гуцикає (Лис 28), книгу тую Адам купив у місті (Лис 116), будемо дівку цюю в'язати (Лис 24), поселили в цюю хату (Лис 113) тощо. У конструкціях як тоє чародійство назвати (Лис 102), Бог і так про теє знає (Лис 180) фіксуємо повні нестягнені форми знахідного відмінка однини вказівного займенника середнього роду. Відповідно до фонетичних особливостей говірок Волинського Полісся В. Лис використовує членні нестягнені форми називного та знахідного відмінків множини вказівних прономінативів із обниженням і розширенням артикуляції наголошеного голосного до [е]: куди ж то шпацірують цеї діди? (Лис 99), покалічать його цеї гицеляки (Лис 261), обоє як теї дрючки (Лис 14), звикла вже в теї двері заходити (Лис 134), в теї, що армії помагають, запишеться (Лис 267).

Народнорозмовну традицію описуваного ареалу передають уживані автором похідні всеньке, всеньку відповідно до староукраїнських вьсє, вьсю: всеньке життє мене так любив (Лис 27), усеньке весілля (Лис 30), була самотньою всеньке життя (Лис 60), усеньке твоє добро (Лис 63), на всеньке село (Лис 181), на всеньку вулицю (Лис 85) та ін.; позначені наслідками прогресивної суміжної асиміляції за способом творення та наявністю протетичного [г] варіанти займенника інший: гинчий чоловік $\epsilon$ (Лис 26), на тамтім, гинчім світі (Лис 180), то вже гинча пісня (Лис 8), на гинчу тобі кебети ни хватить (Лис 23), в гинче село (Лис 70), гинчого чудиська тутика, в цій хаті, й нема (Лис 182), в гинчому місці (Лис 259) тощо; фонетично зумовлені відмінкові форми прономінатива жоден (пор. давні жадный (XIV ст.), жоденъ, жодный (XVII ст.), пор. також із польської żaden «ні один») (Етимологічний словник 2: 204): жєдного так і не вибрала (Лис 26), жєдного чоловіка в школі (Лис 267).

Окремі відмінності супроти літературної мови простежено у фонетичному оформленні, морфемній будові та словозміні неособових неродових займенників.

Дериватами різної структури В.Лис передає народнорозмовну специфіку вживання питально-відносного прономінатива скільки. Так, фіксуємо безпрефіксні утворення, оформлені за допомогою суфікса -ко, якот: кілько то разів до сватання прилучався (Лис 25), килько то літ, Романку, ни заходив? (Лис 25), а також варіанти з префіксом $c$ - та редукцією 


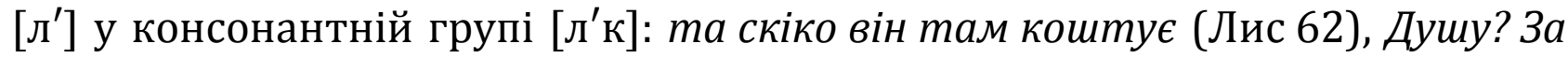
скіко? (Лис 69).

Формотворення питально-відносного займенника що вирізняють говіркові варіанти шо (називний відмінок) та чо (родовий відмінок): а шо, ліпше, як сам загнешся та пару днів пролежиш (Лис 15), а шо ти їм скажеш? (Лис 260), чо ж ни дєкуєш, вилупку? (Лис 23).

Серед форм заперечних займенників зрідка фіксуємо відмінкові вияви 3 історично закономірною часткою ни-: там нихто не провідає (Лис 16). Кількома структурами, що вказують на варіантність в окремій відмінковій позиції діалектної парадигми, представлене формотворення займенника ніщо. Так, В. Лис використовує закріплену літературною нормою форму нічого: нічого, нічого... не там болить (Лис 80); усічений варіант нічо: та я нічо, - Омелян. - Тико ж не приходить (Лис 10), нічо-нічо, сказав дід Пилип. - Я так і ходитиму (Лис 81), нічо, - сказав Адам. - Нічо, то я так (Лис 177); можливе запозичення з польської ніц: ніц доброго тоді не вийшло (Лис 25), мині й ніч ни тре' було (Лис 63), давно ніч не снилося (Лис 63), я ніц не знаю (Лис 118), вже ніц не спитаєш (Лис 128), ти сам ніц не зробиш (Лис 179).

Окремі відмінності простежуємо в оформленні числівників. Так, на позначення числа один (одна, одне) активно вживані форми з початковим [i]], як-от: тико їден раз (Лис 42), лишився їден Платон (Лис 99), тико ж їдна Єва й осталася (Лис 14), хай тико їдне слово скаже (Лис 261), ребро їдне чи й два поламані (Лис 265), їдне місие, де можна од того Максима сховатися (Лис 267); порівняймо живомовний варіант сполуки все одно «однаково»: все їдно до родичів іду (Лис 30), я все їдно не їстиму (Лис 115), корови все їдно треба було пасти (Лис 131), все їдно їм втікати доведеться (Лис 266), гривняка все їдно не вистоїш (Лис 63).

Специфіку оформлення числівника чотири визначила характерна для звукової системи волинсько-поліських говірок регресивна суміжна дисиміляція за способом творення у групі [чт] > [шт]: штири курки (Лис 133), штиром легше, ніж їдному (Лис 69). Форма давального відмінка штиром засвідчує також депалаталізацію сонорного вібранта в кінці основи.

3-поміж інших особливостей числівникової парадигми виокремлюємо оригінальну форму орудного відмінка числівника вісім: потім те тико восьмима дитиськами i обернулося (Лис 22); порівняймо діалектні словозмінні можливості субстантивів у вказаній відмінковій позиції: варе́ник'і з йагуд'ми́ма варили, за две ирми́ма стойі́m' (фіксації автора статті в говірці села Зачернеччя Любомльського району Волинської області).

Про збереження народнорозмовної традиції в системі дієвідмінювання свідчать, зокрема, архаїчні форми II особи множини наказового способу $з$ флексією, позначеною наслідками рефлексації колишнього *ё: вся аж цвіла, мовби казала: он же возьміте, зірвите (Лис 15), Тимкові скажіте (Лис 25), то добре - ждіте, - схвалила жінка (Лис 227). 
Інші відмінності в оформленні дієслів пов'язані з комбінаторними звуковими змінами та регулярними фонетичними процесами, характерними для говірок Волинського Полісся. Так, звукова структура дієслова хотіти нерідко засвідчує наслідки синкопи - випадіння одиничного голосного між приголосними: хтів було і про те нагадати (Лис 26), хтів, щоб я до тебе 3 помелом прийшла (Лис 117), а хіба він хтів утікати (Лис 133), не хтіла його відпускати (Лис 267). Спорадично простежено приклади апокопи, зокрема опускання останнього складу: ой бре, Романиську, ой бре (Лис 101) < брешеш. Фіксовано також усічення особового закінчення: кажи вже, чого хоч' (Лис 100), хоч' на всеньке село наробити сміху? (Лис 181) < хочеш.

Активно вживані В. Лисом дієслівні форми, специфіку звукового складу яких визначає одна з особливостей системи діалектного вокалізму підвищення і звуження вимови наголошеного [а] після м'яких та шиплячих (історично також м'яких) приголосних: ну, глєнь сюди (Лис 23), чо ж ни дєкуєш, вилупку? (Лис 23), і сєду, - сказав Роман (Лис 26), хоч разок ни заглєнув (Лис 27), хоть би домину свою зачинєв (Лис 63), забув иукру взєти (Лис 64), на своїх городах стирчєть (Лис 14), може, од мене блєщину тре', так вибачєй (Лис 100), я ни буду мовчєти (Лис 266).

Виразні говіркові особливості простежено в морфемному складі фіксованих у романі прислівників. Так, прислівник тут - основний засіб реалізації значення 'тут, у цьому місці' - слугує твірною основою для кількох похідних, як-от: тута, тутечки, тутика, пор.: щоб тута лад навести (Лис 64), через десять мінут тута буде поліція (Лис 264), ми тутечки в Адамия посидимо (Лис 13), гинчого чудиська тутика, в цій хаті, й нема (Лис 182).

Продуктивні в живомовній практиці й інші прислівникові деривати 3 формально демінутивними суфіксами -ка, -ика: теперка, теперика, тамика, пор: та все ж час од часу збиралися й теперка (Лис 10), так теперка батюшка те ни схвалює (Лис 12), де їх теперка знаходити? (Лис 15), ти теперка тут хазяїн (Лис 126), теперка там цілий великий кущ, (Лис 133), а типерка давайте обідати (Лис 259), ото теперика радітимуть, як стрінуться (Лис 98), тамика така комизиста дівка була (Лис 24), вона тамика дирехтуркою (Лис 267), він тамика, на Донбасі, офіцером важним (Лис 267). В. Лис активно використовує дериват зновика: Тихіського зновика нима (Лис 10), зновика на старече своє збіговисько? (Лис 23), Єва таки зновика стала веселішою (Лис 33), зновика в хату вернеться? (Лис 40), рушає і зновика спиняється (Лис 60), зновика озирнулася (Лис 62), зновика до нього припреться (Лис 97), а сліз зновика не було (Лис 115), ліворуція зновика в Тупталах (Лис 263) та ін.

Морфемний склад окремих неозначених прислівників вирізняє частка -с'а: у мене деся там липовий цвіт $\epsilon$ (Лис 64).

Спорадично збережено архаїчні форми: тогді ж збиралися (Лис 11).

Висновки та перспективи дослідження. Наведений i проаналізований матеріал дає підстави стверджувати, що В.Лис 
використовує діалектні словоформи та деривати, насичуючи ними мовлення персонажів роману «Стара холера», а також продовжує традицію стилізації авторської мови під говірку на граматичному рівні, що допомагає відтворити народнорозмовну стихію Волинського Полісся.

Найбільш детально передано діалектні відмінності у фонетичному оформленні, морфемній будові та словозміні займенників. Виразними діалектними явищами проілюстровано специфіку формотворення іменників та відмінності в морфемному складі прислівників. Кількома прикладами представлено локальні особливості фонетичного оформлення і словозміни числівників. Одиничними діалектними явищами засвідчено відмінності в системі формотворення прикметників. Обмежено подано специфіку місцевого дієвідмінювання.

Більшість прокоментованих діалектних явищ - морфологічні інновації, причинами появи яких стали типові для волинсько-поліських говірок фонетичні закономірності, а також аналогійні процеси. Архаїчні форми збережено спорадично.

Перспективу дослідження вбачаємо в потребі простежити вияв народнорозмовної традиції на інших мовних рівнях.

\section{Список використаної літератури}

Бевзенко, Степан. Історична морфологія української мови (Нариси із словозміни та словотвору). Ужгород: Закарпатське обласне видавництво, 1960.

Громик, Юрій. «Особливості іменної словозміни в українських говірках берестейськопінського Полісся (на матеріалі записів місцевого фольклору)». Науковий вісник Волинського державного університету імені Лесі Українки: Філологічні науки. Мовознавство, № 7, 2006, с. 282-291.

Етимологічний словник української мови, за ред. О. С. Мельничука. В 7 т. Київ: Наукова думка, 1982-2012.

Єрмоленко, Світлана. «Говіркове багатоголосся сучасної української прози». Українознавство, № 1, 2008, с. 198-205.

Історія української мови. Морфологія, за ред. В. В. Німчука. Київ: Наукова думка, 1978.

Крижанівська, Н. «Короткі форми прикметників в українській мові». Украӥнська мова в школі, № 1, 1960, с. 13-19.

Лис, Володимир. Стара холера: роман. Харків: Книжковий клуб «Клуб сімейного дозвілля», 2018.

Поліщук, Ярослав. Відлуння далекого раю. URL: http:// bukvoid.com.ua/reviews/books/2019/01/05/201146.html

Черевченко, Олександр. «Діалектне слово як функціонально-стилістична одиниця (на прикладі українського поетичного мовлення поч. XX ст.». Мовознавчий вісник: збірник наукових праць, вип. 11-12, 2011, с. 227-231.

Яворський, Андрій. Актуалізація поліських говорів у сучасному художньому тексті. Автореф. дис ... канд. філол. наук: 10.02.01. Луцьк, 2015.

\section{References}

Bevzenko, Stepan. Istorychna morfolohiia ukrainskoi movy (Narysy iz slovozminy ta slovotvoru). Uzhhorod: Zakarpatske oblasne vydavnytstvo, 1960. 
Hromyk, Yurii. “Features of noun's case inflection in sayings of Brest-Pinsk Polissya (on the base of local folklore notes)". Naukovyi visnyk Volynskoho natsionalnoho universytetu imeni Lesi Ukrainky: Filolohichni nauk. Movoznavstvo, no. 7, 2006, pp. 282-291.

Etymolohichnyi slovnyk ukrainskoi movy, edited by O. S. Melnychuk. 7 vols. Kyiv: Naukova dumka, 1982-2012.

Yermolenko, Svitlana. "Dialect Diversity of Modern Ukrainian Prose". Ukrainian Studies, no. 1, 2008, pp. 198-205.

Istoriia ukrainskoi movy. Morfolohiia, edited by V. V. Nimchuk. Kyiv: Naukova dumka, 1978.

Kryzhanivska, N. "Korotki formy prykmetnykiv v ukrainskii movi". Ukrainska mova v shkoli, no. 1, 1960, pp. 13-19.

Lys, Volodymyr. Stara kholera: roman. Kharkiv: Knyzhkovyi klub «Klub simeinoho dozvillia», 2018.

Polishchuk, Yaroslav. Vidlunnia dalekoho raiu. bukvoid.com.ua/reviews/books/2019/ 01/05/201146.html

Cherevchenko, Oleksandr. "Dialect word as a functional-stylistic unit (on the base of Ukrainian poetical speech at the beginning of the XX century)". Movoznavchyi visnyk, iss. 11-12, 2011, pp. 227-231.

Yavorskyi, Andrii. Actualization of the Dialects of Polissia in a Modern Literary Text. PhD Thesis Abstract. Lutsk, 2015. 